\title{
Methane Emission by Ruminants and Its Measurement- A Review
}

\author{
Mokshata Gupta ${ }^{\text {* }}$, Tanmay Mondal ${ }^{2}$, E. Lokesha ${ }^{3}$, Asmita Singh $^{4}$, \\ K. Ashwin ${ }^{5}$, Shahla Perween ${ }^{6}$ and Jatin Kumar Sahoo ${ }^{7}$ \\ ${ }^{1}$ Division of Animal Nutrition, ICAR-Indian Veterinary Research Institute, Izatnagar, \\ Bareilly (U.P.) - 243122, India \\ ${ }^{2}$ Division of Physiology \& Climatology, ICAR-Indian Veterinary Research Institute, \\ Izatnagar, Bareilly (U.P.) - 243122, India \\ *Corresponding author
}

\author{
A B S T R A C T
}

\begin{tabular}{|l|}
\hline Ke y w o r d s \\
Methane, \\
Ruminants, \\
Estimation
\end{tabular}

\section{Introduction}

Livestock and especially ruminants accounts for up to one-third of the emitted methane worldwide (IPCC, 2007). Methane $\left(\mathrm{CH}_{4}\right)$ from agriculture arises primarily from enteric fermentation. Therefore, ruminants are responsible for enteric emissions of $\mathrm{CH}_{4}$ during the normal digestive process. Among ruminants, cattle are the major contributor to greenhouse effect through $\mathrm{CH}_{4}$ emission followed by sheep and goats (Charmley et al., 2008). Fermentation $\mathrm{CH}_{4}$ is the sum of enteric
$\mathrm{CH}_{4}$ and manure $\mathrm{CH}_{4}$ (Mihina et al., 2012). Enteric fermentation is a large source of methane, which has a global warming potential 28 times as strong as that of $\mathrm{CO}_{2}$ on a 100-year time horizon (Stocker et al., 2013). It has been proven to be the second most anthropogenic greenhouse gas (Turner et al., 2016) that accounts for a significant energy loss to the ruminants i.e. about $2-15 \%$ of feed energy (Hess et al., 2004). It accounts for 17$37 \%$ of anthropogenic $\mathrm{CH}_{4}$ (Sejian et al., 2011) from ruminants and its emission depends on several factors like animal species, 
breed, rumen $\mathrm{pH}$, acetate: propionate, dietary composition, etc.

The $\mathrm{CH}_{4}$ emissions from the ruminants is measured as part of the studies related to ruminal fermentation, energy balance, evaluation of feed additives and most recently, to characterize and reduce the contribution of ruminants to the global $\mathrm{CH}_{4}$ production. Methodologies for measuring $\mathrm{CH}_{4}$ emissions range from animal respiration chambers to estimation by model techniques. However, several factors need to be considered in order to select the most appropriate technique like the cost, level of accuracy required and the scale and design of the experiments to be undertaken (Johnson et al., 2000). The commonly used methods for measuring methane emission in ruminants have been discussed in this paper along with their pros and cons. In addition, comparison between them has been done (Table 1).

\section{Respiration calorimeter}

It is the classical standard for measuring ruminant $\mathrm{CH}_{4}$ production. Respiration calorimetry techniques such as whole animal chambers, head boxes, or ventilated hoods and face masks have been effectively used to measure $\mathrm{CH}_{4}$ emissions in ruminants. There are different designs of calorimeters (Blaxter, 1962), but the most common is "open circuit calorimeter". The basic principle behind "open-circuit indirect-respiration technique" is that outside air is circulated around the animal's head, mouth and nose and wellmixed inside air is collected (Mclean and Tobin, 1987) (Fig. 1). The animal is placed inside open-circuit respiration chamber for a period of several days, the inputs (feed, oxygen, $\mathrm{CO}_{2}$ ) and outputs (excretion, oxygen, $\mathrm{CO}_{2}$ and $\mathrm{CH}_{4}$ ) are measured from the chamber. The chamber should be tightly sealed with a slight negative pressure inside. This ensures no net loss of $\mathrm{CH}_{4}$ from the chamber. Internal ventilation fans efficiently mix the expired air and incoming air. An air pump removes all air from the space through flow meter and gas sensor analysis is done. Difference between outgoing and incoming amount of methane is methane emission. Its pros and cons have been mentioned in Table 2.

\section{Sulphur hexafluoride $\left(\mathrm{SF}_{6}\right)$ Tracer Technique}

This method is relatively new and was first described in 1993-1994. This method is primarily used to investigate energy efficacy in free ranging cattle (Okelly et al., 1992). The basic principle is that $\mathrm{CH}_{4}$ emission can be measured if the emission rate of a tracer gas from the rumen is known. For this purpose a non-toxic, physiologically inert (Johnson et al., 1992), stable gas is needed. Additionally, the gas should mix with rumen air in the same way as methane. Therefore, $\mathrm{SF}_{6}$ was chosen because it fulfills all the above criteria, is cheap, has an extremely low detection limit and is simple to analyze.

For individual animal measurement, a calibrated source of $\mathrm{SF}_{6}$ is placed in the rumen before conducting an experiment. The source of $\mathrm{SF}_{6}$ is a permeation tube, and the rate of release of $\mathrm{SF}_{6}$ is controlled by a permeable Teflon membrane held in place by a porous stainless steel frit and a locking nut. The release rate of the gas permeation tube is calibrated at $39^{\circ} \mathrm{C}$ by regular weighing for a period, prior to its insertion into the rumen. Each test animal is fitted with a halter, which supports an inlet tube that is placed so that its opening is close to the nose (depicted in Fig. 2 ). As the vacuum in the sampling canister slowly dissipates, a steady sample of the air around the mouth and nose of the animal is taken. By varying the length and diameter of the capillary tube the duration of sampling may be regulated. The volumes of the canister 
is about 1.7 and 2.5 litres for sheep and cattle respectively, and the capillary system is designed to deliver half this volume during the collection period of $24 \mathrm{~h}$. An identical apparatus needs to be placed each day to collect an integrated background air sample. After collection of a sample, the canister is pressurized with nitrogen, and $\mathrm{CH}_{4}$ and $\mathrm{SF}_{6}$ concentrations are determined by gas chromatography. Methane emission rate is calculated as:

$$
\mathrm{QCH}_{4}=\mathrm{QSF}_{6} \times\left[\mathrm{CH}_{4}\right] /\left[\mathrm{SF}_{6}\right]
$$

Where $\mathrm{QCH}_{4}$ is the emission rate of methane in $\mathrm{g} /$ day; $\mathrm{QSF}_{6}$ is the known release rate (g/day) of $\mathrm{SF}_{6}$ from the permeation tube; $\left[\mathrm{CH}_{4}\right]$ and $\left[\mathrm{SF}_{6}\right]$ are the measured concentrations in the canister.

\section{Rumen Simulation Technique (RUSITEC)}

In the RUSITEC, solid feeds are confined in nylon bags that are normally replaced by new bags once a day. The amount of ration is small (10-25 g DM/day/L of vessel), and the set points of the liquid dilution rate are also small $(25 \% / \mathrm{h})$ as compared with the actual in vivo values (Bhatta et al., 2007b). Its pros and cons have been mentioned in Table 2 .

The gas produced from each fermenter is collected in polythene/rubber bags and the volume of gas is recorded using a dry gas meter. From the gas samples, the concentration of $\mathrm{CH}_{4}$ is measured in gas chromatograph. The volume of $\mathrm{CH}_{4}$ gas produced is calculated from the total volume of gas produced after $24 \mathrm{~h}$ in the fermenter. The $\mathrm{CH}_{4}$ production should be converted to STP value $\left(1 \mathrm{~atm}, 0^{\circ} \mathrm{C}\right)$ for comparison with $\mathrm{CH}_{4}$ measured by other techniques.

Methane in $\mathrm{ml}($ at STP $)=($ Methane $\mathrm{ml}) \times$ $(273 /(273+25)) \times\{($ atmospheric pressure at the experiment) / (standard atmospheric pressure)\}

\section{In Vitro Gas Production Technique (IVGPT)}

Menke et al., (1979) developed a feed evaluation system using an in vitro gas measuring technique. The amount of gas produced during the incubation of feedstuffs with rumen liquor in $100 \mathrm{ml}$ calibrated syringes is closely related to digestibility and therefore to the energetic feed value of feedstuffs for ruminants.

Therefore, on the basis of gas production, quality of feeds can be evaluated. The concentration of $\mathrm{CH}_{4}(\%)$ in the gas samples was determined by the gas chromatograph. Its pros and cons have been mentioned in Table. 2.

\section{Methane models}

During scientific trials using the total national emissions, calculation is not possible. Therefore, methane models have been developed to predict methane production based on existing data, such as animal characteristics (weight, age, and breed), feed characteristics (nutrient and energy content), intake data (dry matter or nutrients) or digested nutrients.

These models frequently uses data derived from experiments conducted with cattle in respiration chambers. The standard model usually used for calculating cattle methane emissions is issued by the IPCC. IPCC (2006) recommends the tier- 2 method for estimating $\mathrm{CH}_{4}$ emissions from enteric fermentation for those countries with large cattle populations. Average daily feed intake (in terms of GE content, $\mathrm{MJ} / \mathrm{d}$ ) and $\mathrm{CH}_{4}$ conversion rates $(\mathrm{Ym})$ are used to estimate $\mathrm{CH}_{4}$ emissions in the tier2 method. For dairy cattle, $\mathrm{Ym}$ is $6.5 \% \pm 1 \%$ of GE intake and for intensively fed cattle ( $>90 \%$ concentrate), $\mathrm{Ym}$ is $3 \%$ of GE. 
Table.1 Comparison between common methane emission techniques

\begin{tabular}{|c|c|c|c|}
\hline Method parameter & $\begin{array}{l}\text { Respiration } \\
\text { Calorimetry }\end{array}$ & $\mathrm{SF}_{6}$ technique & IVGPT \\
\hline Suitability for Individual animals & Yes & Yes & No \\
\hline Variation within animals & Yes & Yes & No \\
\hline Variation between animals & Yes & Yes & No \\
\hline Animal fixation & Yes & Yes & No \\
\hline Effect of physical form of diet & Yes & Yes & No \\
\hline Animals to carry equipment & No & Yes & No \\
\hline
\end{tabular}

Table.2 Pros and cons of methane measuring techniques in ruminants

\begin{tabular}{|c|c|c|c|}
\hline Technique & Pros & Cons & References \\
\hline $\begin{array}{l}\text { Respiration } \\
\text { Calorimeter }\end{array}$ & $\begin{array}{l}\text { Accurate measurement of } \mathrm{CH}_{4} \\
\text { from ruminal and hindgut } \\
\text { fermentations }\end{array}$ & $\begin{array}{l}\text { Not suitable for grazing ruminants, } \\
\text { restriction of animal movement, } \\
\text { construction and maintenance of } \\
\text { the chambers is costly }\end{array}$ & $\begin{array}{l}\text { Bhatta et al., } \\
\text { (2007a) }\end{array}$ \\
\hline $\begin{array}{l}\text { Ventilated } \\
\text { Hood }\end{array}$ & Lower cost & $\begin{array}{l}\text { Requires restrained and trained } \\
\text { animal, hindgut } \mathrm{CH}_{4} \text { can't be } \\
\text { measured }\end{array}$ & $\begin{array}{l}\text { Bhatta et al., } \\
(2007 \mathrm{a})\end{array}$ \\
\hline Facemasks & $\begin{array}{l}\text { Simplicity and lower cost, suitable } \\
\text { for grazing animals }\end{array}$ & $\begin{array}{l}\text { Underestimates heat production, } \\
\text { requires animal cooperation and } \\
\text { eliminates their ability to eat and } \\
\text { drink }\end{array}$ & $\begin{array}{l}\text { Liang et al., } \\
\text { (1989) }\end{array}$ \\
\hline $\begin{array}{l}\text { Sulphur } \\
\text { Hexafluoride } \\
\text { (SF } \text { SF }_{6} \quad \text { Tracer } \\
\text { Technique }\end{array}$ & $\begin{array}{l}\text { Allow the animal to move and } \\
\text { graze freely, suitable for individual } \\
\text { free ranging animals on pasture }\end{array}$ & $\begin{array}{l}\text { Itself it is a GHG with a GWP } \\
23,900 \text { times that of } \mathrm{CO}_{2} \text {, presence } \\
\text { of residue of } \mathrm{SF}_{6} \text { in meat and milk } \\
\text { from farm animals, It is necessary } \\
\text { to train the animal to wear a halter } \\
\text { and collection canister, less } \\
\text { precise, equipment failure }\end{array}$ & $\begin{array}{l}\text { Machmuller and } \\
\text { Hegarty (2005) }\end{array}$ \\
\hline $\begin{array}{l}\text { Rumen } \\
\text { Simulation } \\
\text { Technique } \\
\text { (RUSITEC) }\end{array}$ & $\begin{array}{l}\text { Constructional simplicity and } \\
\text { operational easiness, More number } \\
\text { of fermenters can be used at a time }\end{array}$ & $\begin{array}{l}\text { Difficulty in obtaining a uniform } \\
\text { sample, Protozoa numbers in the } \\
\text { effluent gradually decreases as the } \\
\text { incubation proceeds and settles at } \\
\text { around } 3,000 / \mathrm{ml} \text { after the } 8 \text { th day } \\
\text { for } 3.0 \% / \mathrm{h} \text { dilution rate }\end{array}$ & $\begin{array}{l}\text { Bhatta et al., } \\
(2006,2007 a)\end{array}$ \\
\hline $\begin{array}{l}\text { In Vitro Gas } \\
\text { Production } \\
\text { Technique }\end{array}$ & $\begin{array}{l}\text { Possible to screen many different } \\
\text { feedstuffs fast and cheaply, easy to } \\
\text { control fermentation conditions } \\
\text { like pH, animal to animal } \\
\text { variation- avoided }\end{array}$ & $\begin{array}{l}\text { It only simulates ruminal } \\
\text { fermentation of feed, not emissions } \\
\text { and digestibility by the entire } \\
\text { animal }\end{array}$ & $\begin{array}{l}\text { Czerkawski and } \\
\text { Breckenridge } \\
\text { (1977) }\end{array}$ \\
\hline
\end{tabular}


Fig.1 Open-circuit calorimeter

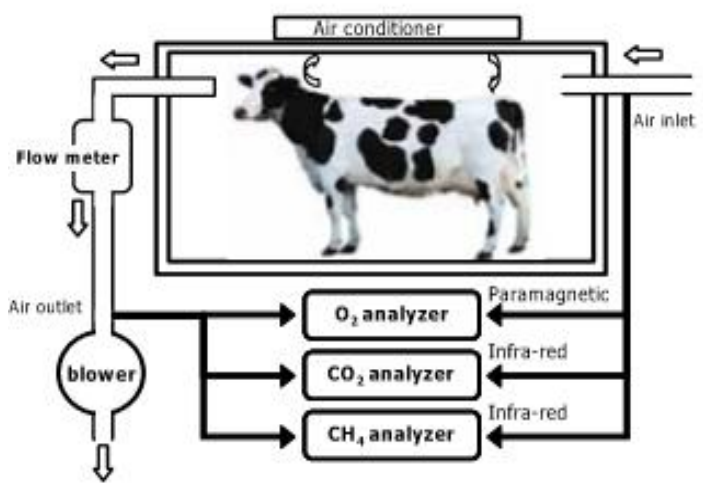

Fig.2 Illustration of SF6 tracer technique (Johnson et al., 1994)

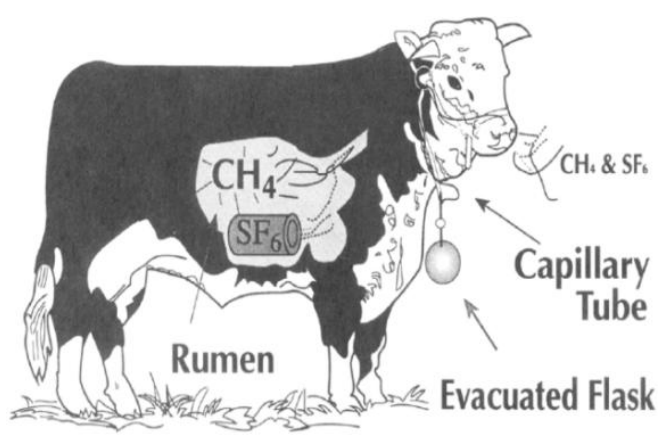

There are 2 types of models:

1) Empirical (statistical) model: Relates nutrient intake to $\mathrm{CH}_{4}$ output directly.

Moe and Tyrrell model (2006): It is an empirical model. It uses data from cattle and relates intake of carbohydrate fractions to $\mathrm{CH}_{4}$ production

Methane $(\mathrm{MJ} / \mathrm{d})=3.41+0.51 \mathrm{NFC}+1.74 \mathrm{HC}+$ $2.65 \mathrm{C}$

where, $\mathrm{NFC}=$ non-fibre carbohydrate $(\mathrm{kg} / \mathrm{d})$; $\mathrm{HC}=$ Hemicellulose $(\mathrm{kg} / \mathrm{d})$; and $\mathrm{C}=$ cellulose $(\mathrm{kg} / \mathrm{d})$.
Dynamic mechanistic model: Attempts to simulate methane emission based on mathematical description of ruminal fermentation biochemistry.

MOLLY Model: It is dynamic mechanistic model of nutrient utilization in cattle. Ruminal $\mathrm{CH}_{4}$ production was predicted to be based on hydrogen balance.

\section{Advantages of mechanistic model}

They are diet-specific, average values are used to emphasize the magnitude of differences in $\mathrm{CH}_{4}$ emissions when using apparently similar $\mathrm{Ym}$ values to estimate national inventory. 
Mitigation options implemented at a farm or national level can be assessed for their effectiveness (empirical models- only reductions in emissions can be assessed).

In conclusion, many good methods for measuring $\mathrm{CH}_{4}$ emissions from ruminants are already in use and new ones are being developed. All these methods require careful consideration before application. In this context, a thorough knowledge of the pros and cons of experimental methods is extremely important. The choice of a method depends on the accuracy. Increased understanding and improved quantification of $\mathrm{CH}_{4}$ production has implications not only for global environmental protection but also for efficient animal production.

\section{References}

Bhatta, R., Enishi, O. and Kurihara, M. (2007a). Measurement of methane production from ruminants. Asian Australasian Journal of Animal Sciences. 20(8): 1305-1318.

Bhatta, R., Enishi, O., Takusari, K., Higuchi, N., Nonaka, I. and Kurihara, M. (2007b). Diet effects on methane production by goats and a comparison between measurement methodologies. J. Agric. Sci. Camb. 146: 705-715.

Bhatta, R., Tajima, K., Takusari, N., Higuchi, K., Enishi, O. and Kurihara, M., 2006, July. Comparison of sulfur hexafluoride tracer technique, rumen simulation technique and in vitro gas production techniques for methane production from ruminant feeds. In International Congress Series (Vol. 1293, pp. 58-61). Elsevier.

Blaxter, K.L. 1962. The Energy Metabolism of Ruminants. London, Hutchinson.

Charmley, E., Stephensand, M.L and Kennedy, P.M. (2008). Predicting livestock productivity and methane emission in northern Australia: development of a bio-economic modeling approach. Australian Journal of Experimental Agriculture. 48: 109-113.

Czerkawski, J. W. and G. Breckenridge. (1977). Design and development of a long-term rumen simulation technique (RUSITEC). Br. J. Nutr. 38: 371-384.

Hess, H.D., Beuret, R.A., Lotscher, M., Hindrichsen, I.K., Machmuller, A and Carulla, J.E. (2004). Ruminal fermentation, methanogenesis and nitrogen utilization of sheep receiving tropical grass hay-concentrate diets with Sapindus saponaria fruits and Cratylia argentea foliage. Anim. Sci. 79: 177-189.

IPCC. IPCC Guidelines for National Greenhouse Gas Inventories. (2006). Available online: http://www.ipccnggip.iges.or.jp/public/2006gl/vol4.ht $\mathrm{ml}$ (accessed on 30 January 2012).

IPCC. Climate Change 2007: Mitigation of Climate Change. IPCC Fourth Assessment Report (AR4). (2007). Availableonline:http://www.ipcc.ch/p ublications_and_data/ar4/wg3/en/cont ents.html (accessed on 30 January 2012)

Johnson, K.A., Huyler, M., Pierce, C.S., Westberg, H., Lamb, B and Zimmerman, P. (1992). The use of $\mathrm{SF}_{6}$ as an inert gas tracer for use in methane measurements. J. Anim. Sci. 70:302.

Johnson, K., Huyler, M., Westberg, H., Lamb, B. and Zimmerman, P. (1994). Measurement of methane emissions from ruminant livestock using a sulfur hexafluoride tracer technique. Environmental science \& technology, 28(2): 359-362.

Johnson, D.E., Johnson, K.A., Ward, G.M and Branine, M.E. (2000). Ruminants and other animals. In: Atmospheric 
Methane: Its Role in the Global Environment, (Ed. M.A.K. Khalil), Springer-Verlag, Berlin Heidelberg, pp. 112-133.

Liang, J.B., Terada, F and Hamaguchi, I. (1989). Efficacy of using the face mask technique for the estimation of daily heat production of cattle. In: (Ed. Y. Van Der Honing and W. H. Close). Energy Metabolism of farm Animals. Pudoc, Wageningen, the Netherlands.

Machmuller, A and Hegarty, R.S. (2005). Alternative tracer gases for the ERUCT technique to estimate methane emission from grazing animals. 2nd International Conference on Greenhouse Gases and Animal Agriculture, Zurich. pp. 365-368.

McLean, J.A. and G. Tobin. (1987). Animal and human calorimetry. Cambridge university press. New York.

Menke, K.H and Steingass, H. (1988). Estimation of the energetic feed value obtained from chemical analysis and gas production using rumen fluid. Anim. Res. Dev. 28: 7-55.

Mihina, S., Kazimirova, V and Copland, T.A. (2012). Technology for farm animal husbandry. Nitra. Slovak Agricultural university. 1: 99.

Moe, P.W. and Tyrell, H.F. (1979). Methane production by dairy cows. J. Dairy Sci. 62:1583-1586.

Okelly, J.C and Spiers, W.G. (1992). Effect of monensin on methane and heat productions of steers fed lucerne hay either ad-libitum or at the rate of 250 g/hour. Aust. J. Agric. Res. 43:17891793.

Sejian, V., Lal, R., Lakritz, J and Ejeji, T. (2011). Measurement and prediction of enteric methane emission. International Journal of Biometeorology. 55: 1-16.

Stocker, T. F., Qin, D., Plattner, G.-K., Tignor, M., Allen, S. K., Boschung, J., Nauels, A., Xia, Y., Bex, V., and Midgley, P. M. Climate Change 2013: The Physical Science Basis, Tech. rep., pp. 1535.

Turner, A.J., Jacob, D.J., Benmergui, J., Wofsy, S.C., Maasakkers, J.D., Butz, A., Hasekamp, O. and Biraud, S.C. (2016). A large increase in US methane emissions over the past decade inferred from satellite data and surface observations. Geophysical Research Letters. 43(5): 2218-2224.

\section{How to cite this article:}

Mokshata Gupta, Tanmay Mondal, E. Lokesha, Asmita Singh, K. Ashwin, Shahla Perween and Jatin Kumar Sahoo. 2018. Methane Emission by Ruminants and its Measurement- A Review Int.J.Curr.Microbiol.App.Sci. 7(07): 3120-3126. doi: https://doi.org/10.20546/ijcmas.2018.707.364 